\title{
Marrow transplantation in treatment of children with aplastic anaemia or acute leukaemia
}

\author{
F. L. JOHNSON, J. R. HARTMANN, E. D. THOMAS, R. L. CHARD, J. A. HERSMAN, \\ C. D. BUCKNER, R. A. CLIFT, and R. STORB \\ From the Departments of Medicine and Pediatrics, University of Washington School of Medicine; \\ Providence Medical Center; and Children's Orthopedic Hospital and Medical Center, Seattle, \\ Washington
}

\begin{abstract}
Johnson, F. L., Hartmann, J. R., Thomas, E. D., Chard, R. L., Hersman, J. A., Buckner, C. D., Clift, R. A., and Storb, R. (1976). Archives of Disease in Childhood, 51, 403. Marrow transplantation in treatment of children with aplastic anaemia or acute leukaemia. Seventy-six patients, aged 2 to 17 years, were treated with bone marrow transplantation for severe aplastic anaemia or acute leukaemia refractory to conventional therapy. 16 of the 22 patients (73\%) who received marrow transplantations for aplastic anaemia are surviving, 12 of these for over one year. In acute leukaemia, using preparation with cyclophosphamide and total body irradiation, 8 of 33 patients (24\%) receiving allogeneic and 5 of $8(63 \%)$ receiving syngeneic transplantations are continuing in remission from 3 months to beyond 2 years. The longest continuing remission off therapy is now over $4 \frac{1}{2}$ years after preparation with total body irradiation. The major causes of failure remain graft-versus-host disease, infection, graft rejection (aplastic anaemia), and leukaemic relapse.
\end{abstract}

The experience of our division with bone marrow transplantation for the treatment of aplastic anaemia or acute leukaemia in all age groups has been the subject of several recent reviews which give in detail the historical background, patient and donor selection and preparation, the transplantation procedure, and post-transplantation management (Buckner et al., 1973; Johnson et al., 1974; Storb et al., 1974a; Thomas et al., 1975). This report summarizes our experience with 76 patients aged

\section{Abbreviations}

ALL: acute lymphoblastic leukaemia

AML: acute myeloblastic leukaemia

ATG: antithymocyte globulin

CNS: central nervous system

CY: cyclophosphamide

GVHD: graft-versus-host disease

MLC: mixed lymphocyte culture

MTX: methotrexate

TBI : total body irradiation
17 years and under, emphasizing the encouraging results currently beng obtained in paediatric patients, particularly in severe aplastic anaemia.

\section{APLASTIC ANAEMIA Pretransplantation}

Twenty-two patients were referred for marrow transplantation for aplastic anaemia. At the time of referral all patients showed clinical and haematological values which are generally accepted as representing severe aplastic anaemia (Table I). The detailed case histories of 11 of these patients have been reported (Storb et al., 1974a).

The basic conditioning regimens were CY $50 \mathrm{mg} / \mathrm{kg}$ per day for 4 days (20 patients) and 1000 rads of TBI (2 patients) Storb et al., 1974a). The age of the donors varied from 8 to 29 years and the bone marrow yield ranged from $1.6 \times 10^{8}$ to $9.4 \times 10^{8}$ nucleated cells $/ \mathrm{kg}$ of recipient (median $5 \cdot 2 \times 10^{8} / \mathrm{kg}$ ). Marrow engraftment was proved by sex chromosome analysis of marrow and peripheral blood lymphoid cells in 11 patients whose donor was of opposite sex, and by red blood cell antigen differences in 5 patients whose donor had a different red blood cell antigen marker. A specific marker was not available in 6 patients. 
TABLE I

Profile of 22 children transplanted for aplastic anaemia

$\begin{array}{ll}\text { Aetiology }(\mathrm{n}=22) & 16 \\ \text { Unknown } & 2 \\ \text { Hepatitis associated } & 3 \\ \text { Probable Fanconi's anaemia } & 1 \\ \text { Paroxysmal nocturnal haemoglobinuria } & \\ & \\ \text { Clinical parameters } & 11(2-17) \\ \text { Age (years) (mean \& range) } & 12: 10 \\ \text { Males: females } & 4(0 \cdot 5-41) \\ \text { Months from diagnosis (median \& } & 5(23 \%) \\ \quad \text { range) } & 8(36 \%) \\ \text { Platelet refractory (n) } & 6(27 \%) \\ \text { History of serious haemorrhage (n) } & 8(36 \%) \\ \text { History of family transfusions (n) } & 20(91 \%) \\ \text { Seriously infected (n) } & \\ \text { No. failing androgens } \pm \text { steroids } & \\ & 220 / \mathrm{mm}^{3}(0-1400) \\ \text { Laboratory parameters } & 5000 / \mathrm{mm}^{3}\left(1 \cdot 2-46 \times 10^{3}\right) \\ \text { Granulocyte count (median \& range) } & \\ \text { Platelet count (median \& range) } & 18(82 \%) \\ \text { Marrow cellularity <10\% } & 21(95 \%) \\ \quad \begin{array}{l}\text { Myeloid (n) } \\ \text { Megakaryocyte (n) }\end{array} & \end{array}$

\section{Post-transplantation}

Sixteen of the 22 patients $(73 \%$ ) were alive from 3 to 46 months after transplantation, 12 more than 1 year. Specific therapy was discontinued for all from day 95 after transplantation, the final day of the MTX course given to prevent or ameliorate GVHD. All normal lives with return to full activity, though one patient has residual hepatic GVHD manifested predominantly by raised concentrations of serum bilirubin and alkaline phosphatase (Table II). The major causes of morbidity and mortality after grafting were (a) infectious complications related to granulocytopenia and immunosuppression, (b) GVHD, (c) failure to engraft and graft rejection, and (d) problems such as CY cystitis and hepatic haemorrhage. have normal bone marrow function and 15 are leading

Infectious complications. All but 1 patient developed an infection in the first 100 days after transplantation. There is an increased risk of infection due to granulocytopenia during the first 21 days, and from immunoincompetence during the first 3 months. The specific infections encountered are presented in Table III. It is important to note that only in those patients with an underlying complication such as graft rejection, severe GVHD, or failure to engraft, did these infections prove fatal, either from refractory Gram-negative septicaemia or from bilateral interstitial pneumonia.

GVHD. 10 of the 21 patients $(48 \%)$ who obtained a functioning graft developed GVHD between 5 and 48 days (median 27 days) after bone marrow infusion. In 4 of the 10 patients the GVHD was very mild, manifested only by a transient generalized erythematous macular rash. In the other 6 affected patients the liver was involved, and 3 of these also had involvement of the gastrointestinal tract. Of this latter group, 4 patients died, 3 with refractory Gram-negative septicaemia and 1 with bilateral interstitial pneumonia. 1 patient treated with ATG therapy as previously described (Storb et al., 1974b), showed a definite improvement but liver function tests still showed residual abnormalities 13 months after transplantation. 2 patients have continuing skin involvement due to GVHD at 20 and 23 months, respectively. In 1 patient this is a significant cosmetic problem with progressive desquamation, pigmentation, and contractures.

Graft rejection. This accounted for only two failures in this age group. The feature common to both patients was a history of transfusions from a family member before bone marrow grafting. In each instance the rejection was evident by day 21 after marrow infusion. Attempts were made to regraft both patients using TBI as a preparative regimen. In one instance engraftment was not obtained and the patient died of Gram-negative septicaemia 19 days later. The second patient, who also received ATG and procarbazine be-

\section{TABLE II}

Aplastic anaemia-results

\begin{tabular}{|c|c|c|c|c|c|c|c|c|c|c|}
\hline \multirow{3}{*}{$\begin{array}{c}\text { Basic } \\
\text { conditioning }\end{array}$} & \multirow{3}{*}{$\begin{array}{l}\text { No. of } \\
\text { patients }\end{array}$} & \multirow[b]{3}{*}{ No. } & \multicolumn{5}{|c|}{ Survivors } & \multicolumn{3}{|c|}{ Nonsurvivors } \\
\hline & & & \multicolumn{4}{|c|}{ Duration (m) } & \multirow{2}{*}{$\begin{array}{l}\text { Present } \\
\text { status }\end{array}$} & \multirow[b]{2}{*}{ No. } & \multirow[b]{2}{*}{ Reason } & \multirow{2}{*}{$\begin{array}{l}\text { Survival } \\
\text { (m) }\end{array}$} \\
\hline & & & $<6$ & $6-12$ & $>12$ & $>20$ & & & & \\
\hline TBI & 20 & 15 & - & - & - & 8 & $\begin{array}{l}13 \text { normal; } \\
2 \text { residual } \\
\text { GVHD } \\
1 \text { normal }\end{array}$ & 1 & $\begin{array}{l}3 \text { GVHD ( } 2 \text { Gram-negative } \\
\text { sepsis) ; (1 pneumonia) } \\
2 \text { rejection ( } 2 \text { Gram- } \\
\text { negative sepsis) } \\
1 \text { no take (Gram-negative } \\
\text { sepsis) }\end{array}$ & $\begin{array}{c}0.5,2 \\
9^{2,2} \\
1\end{array}$ \\
\hline Overall & 22 & $\begin{array}{c}16 \\
(73 \%)\end{array}$ & 3 & 1 & 3 & 9 & $\begin{array}{r}14(64 \%) \\
\text { normal }\end{array}$ & 6 & $\begin{array}{l}3(14 \%) \text { GVHD; } 2(9 \%) \\
\text { rejection; } 1(4 \%) \text { no take }\end{array}$ & $0 \cdot 5-9$ \\
\hline
\end{tabular}

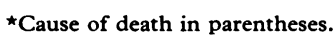


TABLE III

Incidence of infectious complications ${ }^{\star}$ in aplastic anaemia

\begin{tabular}{|c|c|c|c|c|c|}
\hline $\begin{array}{l}\text { Day } \\
0-30\end{array}$ & No. & $\begin{array}{c}\text { Day } \\
30-100\end{array}$ & No. & $\begin{array}{c}\text { Day } \\
100+\end{array}$ & No. \\
\hline $\begin{array}{l}\text { Bacterial }(\mathrm{n}=14) \\
\text { Local infection } \\
\text { Pseudomonas ulcer } \\
\text { Pseudomonas otitis } \\
\text { Esch. coli urinary tract } \\
\text { infection }\end{array}$ & $\begin{array}{l}3 \\
1 \\
1 \\
1\end{array}$ & $\begin{array}{l}\text { Bacterial }(\mathrm{n}=6) \\
\text { Local infection } \\
\text { Staphylococcal bronchitis } \\
\text { Esch. coli } \text { sinusitis }\end{array}$ & $\begin{array}{l}2 \\
1 \\
1\end{array}$ & $\begin{array}{l}\text { Bacterial }(\mathbf{n}=2) \\
\text { Pneumococcal pneumonia }\end{array}$ & 2 \\
\hline $\begin{array}{l}\text { Septicaemia } \\
\text { Multiple Gram-negativet } \\
\text { Esch. coli } \\
\text { Klebsiella } \\
\text { Pseudomonas } \\
\text { Bacteroides } \\
\text { Diphtheroid }\end{array}$ & $\begin{array}{r}11 \\
2 \\
3 \\
2 \\
2 \\
1 \\
1\end{array}$ & $\begin{array}{l}\text { Septicaemia } \\
\text { Esch. coli } \\
\text { Staphylococcus }\end{array}$ & $\begin{array}{l}4 \\
2 \\
2\end{array}$ & & \\
\hline $\begin{array}{l}\text { Viral }(n=2) \\
\text { Viral pneumona }\end{array}$ & 2 & $\begin{array}{l}\text { Viral }(\mathbf{n}=8) \\
\text { Herpes zoster } \\
\text { Viral pneumoniat } \\
\text { Enteritis }\end{array}$ & $\begin{array}{l}4 \\
3 \\
1\end{array}$ & $\begin{array}{l}\text { Viral }(\mathrm{n}=4) \\
\text { Hepatitis } \\
\quad \text { Herpes zoster }\end{array}$ & $\begin{array}{l}1 \\
3\end{array}$ \\
\hline $\begin{array}{l}\text { Fungal ( } \mathrm{n}=1 \text { ) } \\
\text { Candida septicaemiat }\end{array}$ & 1 & $\begin{array}{l}\text { Fungal }(\mathbf{n}=2) \\
\text { Aspergillus sepsis } \\
\text { Candida sepsis }\end{array}$ & $\begin{array}{l}1 \\
1\end{array}$ & & \\
\hline
\end{tabular}

$\star$ Excludes oral candidiasis.

tFatal infections.

fore TBI, obtained a graft, developed GVHD, and died 32 days later of overwhelming Gram-negative septicaemia.

Failure to engraft. The only patient in this series showing no evidence of a functioning graft was prepared with TBI. He also had a history of previous transfusions from a family member and after grafting the clinical course was complicated by recurrent Gramnegative septicaemia. He died on day 24 with pulmonary haemorrhage and antibiotic-resistant bacterial septicaemia.

\section{Miscellaneous problems.}

CY cystitis. CY cystitis manifest by haematuria, frequency, and dysuria was not a significant problem despite a preparation involving such high doses of the drug, and affected only 4 of 20 patients. Only one of these, a 6-year-old girl with probable Fanconi anaemia, required operation with cystoscopy and fulguration. She had previously received CY for presumed autoimmune thrombocytopenia, the first manifestation of her aplastic anaemia. Haematuria started 79 days after transplantation and persisted for over 6 months, principally as microscopical haematuria, before completely resolving.

Hepatic haemorrhage. The same patient with severe haemorrhagic cystitis also developed a diffuse haemorrhage into the liver 22 days after grafting associated with thrombocytopenia. This was ultimately proved on liver biopsy, liver function tests, and a liver scan indicating a diffuse hepatic process. This progressed to portal hypertension but albumin infusions, diuretic therapy, and resolution of the haemorrhage eventually led to complete recovery and return of liver size to normal within 6 weeks.

\section{Discussion}

It is clear from this group of patients that bone marrow transplantation offers an alternative form of therapy to the child with severe life-threatening aplastic anaemia who has an ABO-compatible sib matched at the HL-A and MLC loci. The results of this therapy in our patients indicate that in severe childhood aplastic anaemia the morbidity of marrow transplantation is much less than many paediatricians fear, and that the outlook for longterm survival is extremely good.

The use of a minor sib as a marrow donor, however, remains an ethical concern. In over 100 transplants in Seattle in which the donor was under 18 years of age, no problems have occurred. To safeguard the normal donor, however, we have had patients reviewed by a judge of the State of Washington and a lawyer appointed by the court as a guardian of the minor donor. The decision in each case has been the same, with the judge ruling that the potential emotional harm in the long run would outweigh the physical risk associated with the procedure. The question of medical ethics in marrow transplantation in childhood has recently been discussed in some detail (Levine et al., 1975). 
There can be little doubt that an alternative form of therapy for childhood aplastic anaemia is needed. Enthusiasm generated by the introduction of therapy with androgenic hormones has been dampened by the demonstration that although the initial remission rate may be higher in patients treated with androgens, the overall long-term survival of approximately $25 \%$ of patients with all forms of aplastic anaemia, from mild to severe, is unchanged from that obtained before the introduction of androgens (Hughes, 1973).

The lack of controlled therapeutic trials and the inability to define specific criteria which might indicate the prognosis for a particular patient at the time of diagnosis have made comparison and definition of the role of androgens, corticosteroids, and supportive care in aplastic anaemia almost impossible. Attempts to correlate marrow morphology, fetal haemoglobin levels, and peripheral blood counts at the time of diagnosis have failed to gain universal acceptance. There seems to be agreement at the present time, however on two points summarized best by $\mathrm{Li}$ and his colleagues (Li, Alter, and Nathan, 1972) who, after reviewing the published reports of acquired aplastic anaemia in childhood concluded (1) that androgen therapy 'is only apt to modify the natural history of the milder cases', and (2) 'that survival in aplastic anaemia is chiefly determined by the intensity of the disease'.

Defining the 'intensity' of the disease presents the greatest problem now. Davis and Rubin (1972), in a series of 24 patients with acquired aplastic anaemia, reported a mortality rate of $75 \%$, all but one patient dying within 6 months of diagnosis. They felt that profound granulocytopenia $\left(<700 / \mathrm{mm}^{3}\right)$ and infectious and haemorrhagic complications early in the disease indicated severe aplasia. To this must be added increasing transfusion requirements, particularly with platelets. The best guide then to prognosis in a particular patient does not appear to be related to a specific laboratory measurement, such as marrow morphology or the level of peripheral blood counts at the time of diagnosis, but rather to the frequency of infectious or haemorrhagic complications. In the patients presented here a deteriorating course led to referral for marrow grafting.

Improved supportive care with broad spectrum antibiotics and the availability of random platelet and matched platelet and granulocyte transfusions may enable more patients to survive otherwise lethal infections and haemorrhagic complications in the first 6 months of the disease, thereby increasing the chance of a spontaneous remission or a response to androgen therapy. At the present time this is the only therapy available to the patient who does not have a suitably matched donor for bone marrow transplantation. It should be stressed that the patients who can be supported beyond 6 months will usually require transfusions from HL-A matched donors or family members because of the rapid development of resistance to random platelet transfusions (Grumet and Yankee, 1970). Experience in the canine model and in our patients has emphasized the deleterious effect that transfusions from family members have on subsequent marrow transplantation, leading, because of sensitization to minor transplant antigens, to a high incidence of graft rejection (Storb et al., 1974a, 1970). In view of a mortality rate greater than $70 \%$ when patients with all the grades of aplastic anaemia from mild to severe are considered, it appears from this study and individual case reports (Neiman et al., 1974) that marrow transplantation is the course to follow in the patient with severe aplastic anaemia who does have an HL-A matched sib.

The data presented suggest that reluctance to refer a suitable patient for marrow transplantation because of fear of its hazards is not justified. Half of the patients who are now leading normal lives at 1 year after transplantation were discharged from the hospital within 3 weeks of marrow infusion. The majority of patients did suffer at least 1 infection after transplantation, but in the absence of severe GVHD it was possible to carry them through these episodes. The immunological problems remain the major cause of failure and are the subject of continuing research (Storb et al., 1974a, 1974b).

\section{ACUTE LEUKAEMIA \\ Allogeneic transplants}

Pretransplantation. 42 children were transplanted for acute leukaemia. 29 patients suffered from acute lymphoblastic leukaemia (ALL). The average age of this group was 9 years, the average number of months from diagnosis was 35 (range 11-77 months) spanning an average number of 3 relapses. All but 6 patients were in marrow relapse and refractory to available conventional chemotherapy at the time of grafting. The reasons for transplantation in marrow remission included lack of effective maintenance agents and refractory lifethreatening CNS disease. 6 patients in relapse required transfusion support on admission and 5 had life-threatening infections such as Gram-negative septicaemia or pneumonia. 13 patients suffered from AML. Their average age was 13 years; all were in relapse with average duration of disease being 13 months. 4 patients had not achieved a remission with conventional chemotherapy. 
7 patients required transfusion support and 5 were seriously infected.

Nine patients were prepared for marrow grafting with 1000 rads of TBI. This form of preparation was associated with an extremely high rate of recurrence in ALL ( 5 of the first 6 children transplanted) and resulted in the addition of CY $60 \mathrm{mg} / \mathrm{kg}$ per day $\times 2$ given 72 hours before TBI in an attempt to reduce the relapse rate. The rationale for choosing $\mathrm{CY}$ has been discussed elsewhere (Neiman et al., 1974). In addition to CY and TBI, 17 patients were given high doses of agents to which their disease had not had maximum exposure, aimed at achieving an even greater antileukaemic effect.

The age of the donors ranged from 2 to 23 years (average 13 years) and the marrow yield ranged from 1.7 to $10.9 \times 10^{8}$ nucleated cells $/ \mathrm{kg}$ of recipient (average $4.8 \times 10^{8} / \mathrm{kg}$ ). 24 patients had a donor of opposite sex and in the 22 patients of this group who achieved a functioning graft all showed only donor cells on cytogenetic analysis of marrow and peripheral blood.

Post-transplantation. After grafting, 9 patients (7 ALL, 2 AML) remain leukaemia-free off all antileukaemic therapy for periods ranging from over 3 months to $4 \frac{1}{2}$ years (Table IV). 7 of these children lead normal lives with full activity and 6 are in remission off therapy for $>1$ year. The major complications encountered were GVHD, infection, and relapse, and the specific reasons the procedure failed are given in Table V.
GVHD. 30 of the 40 patients $(75 \%)$ with functional engraftment developed GVHD (18 of 27 patients with ALL; 12 of 13 patients with AML). The median time of onset of the complication was 25 days, range 8 to 41 days. The manifestations of GVHD varied in severity from a transient erythematous skin rash lasting only a few days to a syndrome characterized by generalized desquamative skin rash, severe liver function abnormality with raised serum bilirubin, serum glutamic oxaloacetic transaminase and serum alkaline phosphatase levels, profuse diarrhoea, and death from infection, usually bilateral interstitial pneumonia. 2 patients have continuing skin involvement with GVHD 12 and 25 months after transplantation, which in one patient has led to a significant cosmetic and functional problem with desquamation, pigmentation, contractures, and generalized debility. GVHD appeared to contribute to the cause of death in 13 of the 30 patients, the final complication being a viral or fungal infection.

Infection. Excluding oral candidiasis, 27 episodes of infection were documented in the first month after transplantation in 42 patients. $52 \%$ of these were bacterial, $41 \%$ presumed viral, and $7 \%$ fungal. Beyond this first month viral infections predominated, accounting for $89 \%$ of the infectious episodes. The types and specific aetiological agents of the infections observed were similar to those seen in patients transplanted for aplastic anaemia. The major difference between this group of patients and patients with aplastic ?naemia was

\section{TABLE IV}

Duration of remissions

\begin{tabular}{|c|c|c|c|c|}
\hline & \multicolumn{2}{|c|}{ TBI } & \multicolumn{2}{|c|}{$\mathrm{CY}+\mathrm{TBI}$} \\
\hline & ALL & AML & ALL & AML \\
\hline $\begin{array}{l}\text { No. } \\
\text { Alive in remission } \\
\text { Duration of remission (m) }\end{array}$ & $\begin{array}{c}7 \\
1(14 \%) \\
>55\end{array}$ & $\begin{array}{l}2 \\
- \\
-\end{array}$ & $\begin{array}{c}22 \\
6(27 \%) \\
>3,>4,>12^{\star} \\
>19,>24,>25\end{array}$ & $\begin{array}{c}11 \\
2(18 \%) \\
>6,>35\end{array}$ \\
\hline
\end{tabular}

^Testicular relapse at 7 months. No marrow relapse at this time.

TABLE V

Cause of death in cases of acute leukaemia

\begin{tabular}{|c|c|c|c|c|c|c|}
\hline \multirow[b]{2}{*}{ Complication } & \multirow[b]{2}{*}{ No. } & \multirow[b]{2}{*}{$\begin{array}{l}\% \text { of total } \\
\text { patients }\end{array}$} & \multicolumn{3}{|c|}{ Associated with } & \multirow[b]{2}{*}{$\begin{array}{c}\text { Survival } \\
\text { (m) }\end{array}$} \\
\hline & & & $\begin{array}{l}\text { Nonfunctioning } \\
\text { graft }\end{array}$ & GHVD & $\begin{array}{l}\text { ATG } \\
\text { therapy }\end{array}$ & \\
\hline $\begin{array}{l}\text { Bilateral interstitial } \\
\text { pneumonia } \\
\text { Relapse } \\
\text { Gram-negative septicaemia } \\
\text { Disseminated varicella } \\
\text { zoster } \\
\text { Cerebral fungal abscess } \\
\text { Pulmonary insufficiency } \\
\text { Hepatic insufficiency }\end{array}$ & $\begin{array}{r}15 \\
12 \\
2 \\
1 \\
1 \\
1 \\
1 \\
1\end{array}$ & $\begin{array}{r}36 \% \\
29 \% \\
5 \% \\
2 \% \\
2 \% \\
2 \% \\
2 \%\end{array}$ & $\begin{array}{l}0 \\
0 \\
2 \\
0 \\
\\
\\
0 \\
0 \\
0\end{array}$ & $\begin{array}{r}11 \\
6 \\
0 \\
1 \\
1 \\
1 \\
1\end{array}$ & $\begin{array}{l}8 \\
0 \\
0 \\
1 \\
1 \\
1 \\
1 \\
1\end{array}$ & $\begin{array}{c}1-6 \\
1->18 \\
1 \\
1 \\
2 \\
11 \\
14\end{array}$ \\
\hline
\end{tabular}


the high incidence of bilateral interstitial pneumonia (23 episodes, 15 fatal) presenting usually in the second or third month with fever, cough, hypoxia, and chest $x$-ray changes of diffuse pulmonary infiltration. This accounted for the death of $45 \%$ of patients in whom the procedure failed. The organism most commonly isolated was cytomegalovirus (Neiman et al., 1973).

All but 4 patients who died of interstitial pneumonia had had severe GVHD and 8 had received ATG therapy. 2 other patients also died of infection after GVHD and ATG therapy, 1 with a cerebral abscess due to Monosporium apiospermum and the other with disseminated varicella zoster. The 2 patients who did not develop a functioning graft died within 21 days from Gram-negative septicaemia.

Relapse. 12 patients (8 ALL, 4 AML) suffered recurrence of leukaemia in the marrow, all but 2 within 6 months of transplantation. The latest marrow relapse has been in a 13-year-old boy with AML who relapsed at 18 months. 2 localized recurrences have been observed. Microscopical foci of lymphoblastic leukaemia were found in the cerebellum and kidney of 1 patient who died of adenovirus pneumonia. A lymphoblastic testicular recurrence occurred at 7 months in another patient. After orchidectomy and local irradiation, this patient remained in complete remission 5 months later. The type of relapse detected when cytogenetic sex chromosome markers have been available has usually been of host origin, but in 2 patients previously reported the relapse was found to occur in donor cells (Fialkow et al., 1971; Thomas et al., 1972).

The addition of CY to TBI has decreased the relapse rate in ALL from 5 out of 6 patients $(83 \%)$ to 4 out of 22 patients $(18 \%)$, though the short survival of many patients may be contributing to a false low relapse incidence. Additional cytoreduction with other cytotoxic agents before CY and TBI does not appear to have further decreased the incidence of relapse.

Miscellaneous problems-CY cystitis. 18 patients $(43 \%)$ developed symptoms and signs of CY cystitis, a higher incidence than that seen in patients with aplastic anaemia. This may reflect a higher incidence of previous exposure to $\mathrm{CY}$ during the course of therapy for acute leukaemia and the addition of irradiation to the transplantation protocol. The range of onset was from the day after the first dose of CY to as late as 86 days after, with a median day of onset of 23 days. The cystitis lasted from 5 days to $>5$ months with a median range of 17 days. In all but 3 patients it was completely controlled by increasing fluid output.

Influence of extramedullary leukaemia and previous radiation. The characteristic of patients now surviving in complete remission $>1$ year after transplantation have not yet shown any single factor favouring a successful outcome. In particular, extramedullary disease does not appear to be associated with a higher incidence of relapse after grafting. Of the 22 patients with ALL prepared with chemotherapy and
TBI, 12 had a history of leukaemic infiltration of the CNS before referral. Those patients with and those without a history of CNS disease were comparable - the duration of disease before transplantation being 41 and 39 months, respectively; the chemotherapeutic histories were similar, and the median survival after grafting was 87 and 91 days, respectively. No patient with previous CNS infiltration died because of recurrence, and no patient living more than 3 months showed evidence of leukaemia at necropsy. In contrast, 3 of the 10 patients without CNS involvement relapsed before grafting.

Radiation therapy at the time of diagnosis has become routine for a large proportion of children with ALL after the demonstration of the value of adjuvant CNS therapy (Pinkel, 1971). The effect of an additional 1000 rads of irradiation given at a dose rate of 5.5 $\mathrm{R} / \mathrm{min}$ becomes extremely important, particularly in those children who have received more than 2000 rads to the spinal cord or to areas which include the gastrointestinal tract, when the radiation tolerance of these tissues may be exceeded. 11 patients had received over 2000 rads of cranial irradiation and 7 of these survived over 3 months after TBI without apparent toxicity, including 1 patient who had received 4000 rads.

The survival of children in the group who additionally received over 2000 rads to the spinal cord has been too short to conclude that transverse myelitis will not occur, but so far 2 children of this group have survived in more than 6 months after TBI without complication. At present, 2000 rads of craniospinal irradiation is not considered a contraindication to marrow grafting.

\section{Syngeneic transplants}

The results of twin transplants for haematological malignancy have recently been published (Fefer et al., 1974) and the following is a summary of these transplants in children.

(1) 8 children have received marrow transplants for ALL. 2 were prepared with TBI only. Both relapsed within 2 months of grafting. 2 were prepared with the CY plus TBI protocol. Both received immunotherapy after grafting. 1 relapsed at 7 months but the second patient is in complete remission at 27 months. 4 patients received cytoreductive therapy consisting of combinations of vincristine, daunorubicin, cytosine arabinoside, L-asparaginase, and 6-thioguanine as well as CY and TBI. 3 of these patients received post-grafting immunotherapy and 2 are alive in remission at 38 months and 9 months. The third patient died in remission with Australian antigen negative viral hepatitis 1 month after grafting. The fourth patient did not receive immunotherapy and relapsed 1 month after grafting.

(2) 2 children received marrow grafts for AML. Both were prepared with CY and TBI, 1 receiving posttransplantation immunotherapy. Both are in remission at 24 and 38 months, respectively.

(3) 2 other children have been transplanted, 1 for chronic myelogenous leukaemia in blast crisis, the second for disseminated lymphosarcoma. Both obtained initial remissions for 4 months and 7 months, respectively. 
Both were regrafted after relapse and temporary remissions of 2 and 3 months were obtained.

Overall, 5 of 10 patients transplanted for acute leukaemia refractory to conventional treatment remain in remission for periods of $>9,24,27,38$, and 38 months, off all therapy.

\section{Discussion}

GVHD, infection, and relapse remain the major problems in allogeneic marrow grafting for acute leukaemia. The development of ATG has been one advance modifying acute GVHD and has been life-saving in some instances. Our overall experience with this method has recently been published (Storb et al., 1974b). More effective antibiotics and granulocyte transfusions have decreased the mortality from Gram-negative septicaemia commonly occurring in the first 3 weeks after transplantation. The major infectious problems, predisposed by the slow immunological recovery of patients after the intensive immunosuppression of the preparation (Fass et al., 1973), GVHD and its treatment with ATG (Storb et al., 1974b), are now of viral aetiology and advances in this area await the development of effective immunization and specific antiviral therapy. The problem of relapse seems to be greatly diminished by the more aggressive regimen which includes $\mathrm{CY}$ as well as TBI, but further cytoreduction with additional chemotherapy has not been of value in eradicating this complication.

Despite these continuing problems the 1-year unmaintained remission rate in this small series exceeds $30 \%$ for allogeneic and $60 \%$ for syngeneic transplants when patients are transplanted at a very late stage in their leukaemia and conditioned with CY and TBI (Table VI). In addition, since 1969, there has been steadily increasing success in that a 1-year complete remission rate exceeding $20 \%$ has now been achieved in 70 allogeneic marrow

\section{TABLE VI}

Follow-up of patients transplanted between June 1969 and January 1974. One-year survival in unmaintained remission rate after $C Y$ and TBI conditioning

\begin{tabular}{c|c|c}
\hline Disease & Syngeneic & Allogeneic \\
\hline ALL & $2 / 4^{\star}(50 \%)$ & $4 / 15(27 \%)$ \\
AML & $2 / 2(100 \%)$ & $3 / 7+(43 \%)$ \\
\hline Overall & $4 / 6(66 \%)$ & $7 / 22(32 \%)$ \\
\hline
\end{tabular}

$\star$ Number alive in remission/number transplanted.

t1 patient died at 15 months from hepatic failure secondary to GVHD. 1 patient relapsed at 18 months. transplants for acute leukaemia when all age groups are considered (Thomas et al., 1975).

In the light of these results obtained in patients with endstage leukaemia, an important question is whether transplantation earlier in the course of disease when the patient is in better clinical condition might not both decrease the early morbidity and improve overall survival. The prognosis of childhood ALL has changed favourably in the past 5 years with the introduction of early sanctuary therapy, particularly to the CNS, and combination maintenance chemotherapy. Major centres are consistently obtaining a $50 \%$ 3-year and continuing first remission rate (Simone et al., 1972). Once these children relapse on such 'total therapy' protocols, however, having been exposed to the best drugs available against ALL, further long remissions in the absence of more effective antileukaemic agents will probably be rare. Our recommendation is that marrow grafting in ALL be considered at the time of the first relapse in children being treated on the current 'total therapy' protocols. The prognosis of childhood AML remains extremely poor, approximately half of the affected patients never achieving remission (Fleming et al., 1974). For this reason, marrow grafting in AML might be considered much earlier, at the time of first relapse or in cases where the patient has not achieved remission after 4 to 6 weeks of conventional therapy.

At a practical level these results indicate that the child with acute leukaemia should have tissue typing performed at the time of diagnosis to discover if there is a suitably matched sib. If the patient has an identical twin or an ABO compatible, HL-A identical, and MLC nonreactive sib then marrow transplantation should be considered as an additional therapeutic option.

The authors thank the physicians, nurses, and technologists of the Leukemia Research Center and Children's Orthopedic Hospital and Medical Center for their dedicated patient care, and Janis Lee for secretarial help.

This investigation was supported by Grants CA 10895, CA 05231, CA 15704, and CA 08157 from the National Cancer Institute. E.D.T. is a recipient of Research Career Award AI 02425 from the National Institute of Allergy and Infectious Diseases.

\section{REFERENCES}

Buckner, C. D., Clift, R. A., Fefer, A., Neiman, P., Storb, R., and Thomas, E. D. (1973). Human marrow transplantationcurrent status. Progress in Hematology, Vol. VIII, p. 299. Ed. by E. B. Brown. Grune and Stratton, New York.

Davis, S., and Rubin, A. D. (1972). Treatment and prognosis in aplastic anaemia. Lancet, 1, 871. 
Fass, L., Ochs, H. D., Thomas, E. D., Mickelson, E., Storb, R., and Fefer, A. (1973). Studies of immunologic reactivity following syngeneic or allogeneic marrow grafts in man. Transplantation 16,630 .

Fefer, A., Einstein, A. B., Thomas, E. D., Buckner, C. D., Clift, R. A., Glucksberg, H., Neiman, P. E., and Storb, R. (1974). Bone-marrow transplantation for hematologic neoplasia in 16 patients with identical twins. New England fournal of Medicine, 290, 1389.

Fialkow, P. J., Thomas, E. D., Bryant, J. I., and Neiman, P. E. (1971). Leukaemic transformation of engrafted human marrow cells in vivo. Lancet, $1,251$.

Fleming, I., Simone, J., Jackson, R., Johnson, W., Walters, T., and Mason, C. (1974). Splenectomy and chemotherapy in acute myelocytic leukemia of childhood. Cancer, 33, 427.

Grumet, F. C., and Yankee, R. A. (1970). Long-term platelet support of patients with aplastic anemia. Effect of splenectomy and steroid therapy. Annals of Internal Medicine, 73, 1.

Hughes, D. W. O'G. (1973). Aplastic anaemia in childhood: a reappraisal. II. Idiopathic and acquired aplastic anaemia. Medical fournal of Australia, 2, 361.

Johnson, F. L., Thomas, E. D., Buckner, C. D., Clift, R. A., Fefer, A., and Storb, R. (1974). The current status of bone marrow transplantation in cancer treatment. Cancer Treatment Reviews, 1, 81.

Levine, M. D., Camitta, B. M., Nathan, D., and Curran, W. J. (1975) The medical ethics of bone marrow transplantation in childhood. Fournal of Pediatrics, 86, 145.

Li, F. P., Alter, B. P., and Nathan, D. G. (1972). The mortality of acquired aplastic anemia in children. Blood, 40, 153.

Neiman, P., Thomas, E. D., Buckner, C. D., Storb, R., Fefer, A., Glucksberg, H., and Lerner, K. G. (1974). Marrow transplantation for aplastic anemia and acute leukemia. Annual Review of Medicine, 25, 179.

Neiman, P., Wasserman, P. B., Wentworth, B. B., Kao, G. F., Lerner, K. G., Storb, R., Buckner, C. D., Clift, R. A., Fefer, A., Fass, L., Glucksberg, H., and Thomas, E. D. (1973).
Interstitial pneumonia and cytomegalovirus infection as complications of human marrow transplantation. Transplantation, 15, 478.

Pinkel, D. (1971). Five-year follow-up of 'total therapy' of childhood lymphocytic leukaemia. Fournal of the American Medical Association, 216, 648.

Simone, J., Aur, R. J. A., Hustu, H. O., and Pinkel, D. (1972). 'Total therapy' studies of acute lymphocytic leukemia in children. Current results and prospects for cure. Cancer, 30, 1488.

Storb, R., Epstein, R. B., Rudolph, R. H., and Thomas, E. D. (1970). The effect of prior transfusion on marrow grafts between histocompatible canine siblings. Fournal of Immunology, 105, 627.

Storb, R., Thomas, E. D., Buckner, C. D., Clift, R. A., Johnson, F. L., Fefer, A., Glucksberg, H., Giblett, E. R., Lerner, K. G., and Neiman, P. (1974a). Allogeneic marrow grafting for treatment of aplastic anemia. Blood, 43, 157.

Storb, R., Gluckman, E., Thomas, E. D., Buckner, C. D., Clift, R. A., Fefer, A., Glucksberg, H., Graham, T. C., Johnson, F. L., Lerner, K. G., Neiman, P. E., and Ochs, H. (1974b). Treatment of established human graft-versus-host disease by antithymocyte globulin. Blood, 44, 57.

Thomas, E. D., Bryant, J. I., Buckner, C. D., Clift, R. A., Fefer, A., Johnson, F. L., Neiman, P., Ramberg, R. E., and Storb, R. (1972). Leukaemic transformation of engrafted human marrow cells in vivo. Lancet: $1,1310$.

Thomas, E. D., Storb, R., Clift, R. A., Fefer, A., Johnson, F. L., Neiman, P. E. Lerner, K. G., Glucksberg, H., and Buckner, C. D. (1975). Bone-marrow transplantation. New England fournal of Medicine, 292, 832, 895.

Correspondence to Dr. E. D. Thomas, Fred Hutchinson Cancer Center, 1124 Columbia Street, Seattle, Washington 98104, U.S.A. 